\title{
Role boundary management during Covid-19 pandemic: A qualitative analysis of focus group data with working-student mothers
}

\author{
Cláudia Andrade ${ }^{1} \&$ Joana Lobo Fernandes ${ }^{1}$ \\ ${ }^{1}$ Politécnico de Coimbra, Escola Superior de Educação
}

\begin{abstract}
This qualitative study explores the experiences of role boundary management of workingstudent mothers during COVID-19 pandemic shelter in place order. A thematic analysis was used to examine the experiences and consequences of role blurring due to remote work, school closures, and remote learning and the strategies used to cope with the demands of three roles - being a mother, a worker, and a student. Eight participants enrolled in higher education programs participated in a focus group using Zoom technology. Several experiences of role blurring and barriers to satisfactorily manage all the roles emerged from the analysis. Strategies to cope with permanent demands seemed to have had only a small effect on working-student mothers' adjustment and well-being as they navigated through the days of shelter in place order. Implications for a better understanding of the experience and impacts of role boundary management during COVID-19 are discussed.
\end{abstract}

\section{Keywords: Working-student-mothers; role boundary management; COVID-19.}

Gestão de fronteiras entre papéis durante a pandemia Covid-19: Um estudo qualitativo com recurso a focus group junto de mães trabalhadoras-estudantes: Este estudo qualitativo aborda as experiências de mães trabalhadoras-estudantes na gestão de fronteiras entre papéis durante o período de confinamento devido à pandemia por COVID-19. Recorreu-se à análise temática para analisar as experiências e as consequências do esbatimento de fronteiras entre papéis decorrente das circunstâncias de trabalho remoto, encerramento das escolas e aprendizagem à distância assim como as estratégias usadas para lidar com as solicitações decorrentes dos três papéis, a saber: mãe, trabalhadora e estudante. Participaram no focus group via Zoom oito estudantes do ensino superior, tendo emergido diversas experiências do esbatimento de fronteiras entre papéis e barreiras a uma conciliação satisfatória de todos estes. Analisaram-se as estratégias para lidar com as solicitações permanentes, sendo que estas parecem ter um efeito reduzido no ajustamento e no bem-estar das mães trabalhadoras-estudantes no dia-a-dia de confinamento. Analisaram-se ainda as implicações da experiência e do impacto do confinamento na gestão dos papéis desempenhados.

Palavras-chave: Mães trabalhadoras-estudantes; gestão de fronteiras entre papéis; COVID-19.

Nontraditional students are a specific group within the higher education population that includes matureage individuals over the age of 23, which often blend this role with other life roles, namely work and parenting. (e.g., Andrade \& Matias, 2017; Choy, 2002; Oliveira \& Temudo, 2009; van Rhijn 2014). Research analyzing the effects of managing multiple roles with samples of the working student parents' population suggests that they face an increased role strain arising from conflicting role obligations (Cinamon, 2016; Park \& Strung, 2013; van Rhijn, 2014; Wyland et al., 2013). Moreover, literature pinpoints that working student parents' challenges and barriers to combine the student role with other life roles are written along "gender lines." Since gender roles often ascribe most of the household chores and childcare burden to women, the research found that combining several roles is particularly complex for female students (Home, 1997; Sweet \& Moen, 2007). Conflicting experiences faced female students with juggling work, family, and the student role have also been identified in studies carried out in Portugal (Andrade et al., 2017; Oliveira \& Temudo, 2009).

If working-student mothers face, in regular times, difficulties in combing multiple roles, the COVID19 pandemic might have brought additional challenges (UNESCO, 2020). The closing of higher education institutions, schools, other childcare facilities, together with the transition to remote instruction, the changes in the workplace to telework or limited on-site work, placed at home both the professional work and the educational instruction. All these actions devoted to simultaneously contain the spread of the virus

${ }^{1}$ Correspondence address: Cláudia Andrade, Escola Superior de Educação, Rua D. João III, 3030-033 Coimbra, Portugal. E-mail: mcandrade@esec.pt 
and to mitigate damage in health systems ended up in a shelter in place order. This reality might have had an impact on working student mothers' unique circumstances. This study aims to examine the experiences and impacts of managing three life roles - being a worker, a mother, and a student - during the COVID-19 pandemic shelter in place order. An exploration of working student mothers' experiences is required to understand better what it is like to manage their multiple roles. Furthermore, an in-depth understanding of working student mothers' experiences in the unique context of COVID-19 is crucial to developing evidence-based forms of support, particularly when both higher education institutions and the labor market seek remote work and learning solutions.

\section{Role of boundary management}

The literature on work-family relations has been used as a conceptual framework that also applies to workfamily-school role reconciliation when analyzing working student parents' particular situation. The seminal work of Nippert-Eng (1996) stated that life roles have boundaries, role boundaries, that are constructs build at the individual level that is often negotiated by the different parties involved, like family members, coworkers, supervisors, and others. Accordingly, role boundary theory assumes that when individuals take on numerous roles, they tend to develop boundaries based on the roles they envision for themselves so that they have a more accurate sense of control over each role (Ashforth et al., 2000; Kreiner et al., 2009). Ashforth et al. (2000) claims that these role boundaries can have some degree of flexibility or permeability, using concepts such as segmentation and integration to describe opposite ends of a continuum. When individuals segment or integrate roles, inter-role conflicts can occur. As it is stated by Kreiner et al. (2009), individuals may experience tensions related to the demands associated with each role, and to cope with those demands satisfactorily, they might need to manage the role boundaries actively. Lowe and Gayle (2007) used role boundary theory to identify work-family-school role balance types with a sample of adult learners. Four types of scenarios were identified: a) segmentation of the roles, b) integration of the student role with the work-family roles through negotiations with key individuals and with fixed solutions, c) integration of the student role with the work-family roles using daily negotiations and d) demands from each role competing for time and energy creating conflicts with negative impacts in the student role.

The present study uses the conceptual framework of role boundary management theory (Kreiner et al., 2009) to understand better how the working-student mothers managed the boundaries of their roles inherent in their three roles during the shelter in place order. Work-family theories have been used to help frame this research and understand how working student mothers manage multiple roles. The experience of role overload and conflict resulting from the perception of having too many competing demands have been found in many studies with samples of female working student parents (Andrade \& Matias, 2017; Home, 1997; Oliveira \& Temudo, 2008; Sweet \& Home, 2007). The effects of the COVID-19 shelter in place order could add an additional layer of complexity in a deal with the competing demands associated with their three roles performed all in the home environment threaten their ability to keep themselves and their families healthy, as well as maintaining both their professionals lives and their studies remotely. Although this is an exploratory study, it is crucial to underline its pioneering character in Portugal and its contribution to a better understanding of the challenges faced by adult learners, like working student mothers, their experiences, and impacts during this exceptional situation of shelter in place order during the pandemic COVID-19.

\section{OBJECTIVES}

The main research question sought to understand how the work, motherhood, and school role boundaries changed as they adapted to the restrictions associated with homeschooling, remote work, and remote learning. We also tried to explore participants' experiences of role reconciliation and the implications for the participants.

\section{METHOD}

\section{Participants}

A total of eight participants contributed to the discussion in one online focus group. Participants ages ranged between 43 to 52 years old (Mage $=46.5, S D=3.299$ ). They are mothers of children with ages ranging from 5 to 28 years old (Mage $=15.75, S D=5.80)$, with one participant being a mother of one child and one participant being a mother of three children. The other six participants have two children. All participants lived with their children in the household, and they are all partnered except for one participant that is divorced. Regarding their student status, three students at the master level and all the others are 
undergraduate students. They all have clerical professions, in different types of public organizations, work full-time, 35 hours per week. During the shelter, in place order, they were working remotely with two participants reporting that they had to work on-site when called, but never more than one day a week.

\section{Procedure}

Participants were recruited by the researchers using their contacts and using a snowball technique. Inclusion criteria involved being a mother of, at least, a child under 18 years old, working full-time while enrolling in an undergraduate program or a master program ( $2^{\text {nd }}$ or $3^{\text {rd }}$ year). To conduct the focus group, we used the Zoom platform. The focus group was held in July of 2020, with a duration of 96 minutes. Interviewers encouraged participants to expand upon their answers. At the end of the focus group, participants were asked to fill a brief demographic questionnaire and sent it back to the authors by email. At the start of the focus group, participants were informed about the research goals, that the data collected will remain anonymous and will be only used for research purposes, and consent to record the session was asked.

\section{Instrument}

Focus group is an advantageous and versatile research method in exploratory studies. It can inspire reflection and discussion of shared experiences and concerns without pressuring each participant to respond to every topic (Basch, 1987). In the present study, the focus group's choice allowed the participants to share and compare their experiences. A semi-structured interview script was used, covering various discussion topics based on the literature review, covering the following topics: How did you manage to combine work, motherhood, and school roles during the shelter in place order? Two interconnected concepts were explored: 1) Strategies they use to cope 2) Feelings they experience during the process.

\section{Data Analysis}

Given the identified new situation created by the shelter in place order due to the pandemic COVID-19, this research was conducted as an exploratory, qualitative study to deepen understanding of working-student mothers' role boundary management experiences. Accordingly, to have an understanding of how they made sense of their experiences, we used an interpretivist/social constructionist paradigm (Daly, 2007) using the Thematic Analysis (TA) method of six steps as defined by Braun and Clarke $(2006,2013)$. During the first phase, authors became familiar with the data by hearing the records and work on the transcript. As a second phase, initial ideas for coding were written, and then initial themes were generated. Phase three consisted of reviewing and refining the initial themes. In phase four, both authors checked whether the data-bound together meaningfully within each theme. In phase five, each theme was considered definitive, and in the sixth phase, a report was written based on excerpts from participants selected to illustrate each theme.

\section{RESULTS AND DISCUSSION}

Three themes have been identified inductively, which we have designed as follows: i) work role spillover family and student role, ii) coping strategies for role boundaryless days, and iii) role management experiences.

\section{Work role spillover family and student role}

Adequately managing the demands of work, motherhood, and school and managing role boundaries during the shelter in place order are identified as a challenge by all participants. They all, excepting one, mention that workload related to worker role to be accomplished within the workday increases, compelling them to extend the time devoted to work-related tasks for periods that included evenings, very early mornings, and weekends. Many describe work-related tasks as taking almost all the time during the day. For example, some participants find themselves unable to escape the constant demands of work experiencing time constraints to accomplish all the work tasks they were asked to perform within the regular work schedule: "It was not easy because I did not have a 9 to 5 pm working schedule (...) when we're at home there is no such a working schedule" (I4, 48y, 2 children, $\left.21 \mathrm{y} / 12 \mathrm{y}^{2}\right)$. Another participant reports: "Even if we want to, it is not easy to separate roles - we need to work and to be responsive to the work calls" (I8, 43y, 2 children, 10y/9y). Nippert-Eng (1996) mentioned that even though some individuals might have some preferences for segmenting their life roles, in most cases, their situations played an essential role in how they fall into their preferences. It seemed that the demands of the work role spilled over other roles, creating a centrality

${ }^{2}$ Interviewee \#4, 48 years old, mother of two children, aged 21 and 12 years old. 
in time and energy to be devoted felt for almost all the participants. As Ashforth et al. (2000) found, involuntary role integration can cause tensions and stress for individuals who must adjust to roles overlapping for some periods of time. As Kreiner et al. (2009) claims, involuntary intrusion of one role in another role creates a sense of boundary violation, triggering negative emotions and exhaustion. This seems to be the case in the present study. Almost all the participants mention the theme of overall dissatisfaction with the need to extend the workday to get their professional work done.

Consequently, a considerable number of participants mention that they have to make daily decisions regarding what or who should take priority. They note that they find ways of allocating a specific time frame (e.g., very early in the morning or late in the evening) to accomplish their school and work tasks and attend remote learning classes. As one participant notes: "I did not want to leave any tasks behind, I wanted to have everything done. Thus, evening time was always another working shift (...) homeschooling for my children and work during the day, and schoolwork for me during the evening" (I8, 43y, 2 children, 10y/9y). Participants with younger children also report how organizing their time for work and school is a challenge. One participant mentions: "First, I missed the daily routines (...). It ended up all well, at the family level, and the kids did well at school" (idem). However, it should be noted that even though students feel strained for time, there is also a confidence in the discourse associated with the way they spent time with their children.

\section{Coping strategies for role boundaryless days}

Existing literature has demonstrated that the management of the student role with the work-family roles by using daily negotiations and asking for help from partners, family, friends, children, was a strategy used by working student parents to meet their work, family, and school responsibilities (Lowe \& Gayle, 2007; van Rhijn, 2014). Seeking support from coworkers, school mates or even institutional support is also identified as a coping strategy by some participants. As one participant notes about peer support: "I always kept up with my school mate, using zoom, to study together and work on the school assignments" (I7, 44y, 1 child, 18y). Institutional support was also activated in some cases. One participant mentioned: "We did not have laptops for everybody at home. We asked the school to provide a laptop for one of my children?" (I8, 43y, 2 children, 10y/9y).

\section{Role management experiences}

In what concerns their assessment of the role boundary management, feelings of frustration based on the incapability to satisfactorily accomplish all the school tasks are manifest in several responses. The following quote illustrates it: "Working remotely made it hard for me to have routines for studying. I used to study in the college library" (I2, 52y, 2 children, 20y/15y). She added, "I first thought that being always at home would allow me to do a lot of things (...). It did not happen (...) I was tired of being all day in the same place" (idem). Moreover, feelings of pressure are also verbalized: "For me working remotely was an overwhelming experience. I hope I will not have to face again in the future" (I1, 52y, 3 children, 28y, 21y, 16y). The same participant adds: "There was a day that I "crashed": I felt badly, and dizzy" (I1, 52y, 3 children, 28y, 21y, 16y).

\section{CONCLUSION, LIMITATIONS AND FUTURE DIRECTIONS}

The COVID-19 pandemic and shelter in place order challenged working student mothers' abilities to navigate their three roles. While some tactics used were described, the pressures to adequately manage the three roles within the home environment became evident in the discourse. Our results follow the claim of Chawla et al. (2020) that found that remote professional work at home limited the segmentation between work and private life, often leading to more significant difficulties in "switching off" from work responsibilities. Moreover, the demands related to shelter in place orders that moved work and schools to home have blurred work and family roles, making it more problematic to find ways to satisfactorily manage role boundaries (Carnevale \& Hatak, 2020). In addition to managing work and family demands, remote online learning due to education institutions' suspension added another layer of complexity and strain to the working-student mothers. While the blurred work, family, and school roles increased the potential for conflict among the roles, it seemed that the pressures from the work role spillover the other roles, with an impact on the student role that was the one that appeared to be more constrained. An interesting result of this study was related to the fact that some participants activated different forms of support at work and school. Still, family support, namely from the partners, was never mentioned. This is consistent with research that claims that school enrollment should preserve the work-family role reconciliation for women, and they should find ways of successfully combining the three roles (Andrade \& Matias, 2017). It should 
also be noted that most of the participants of this study were mothers of teenagers who can also account for the positive results that were mentioned in what concerns the fulfillment of the mother role.

Given the pandemic's uncertain nature, remote work appears to have had a more significant impact on blurring role boundaries, creating disruptive impacts in the management of work-family-school roles and harmful individual impacts. This result is in line with previous studies that the work role (e.g., lack of flexibility and support) can hinder the education process (Andrade \& Matias, 2017). Thus, this impact should be analyzed deeper in further studies.

This study has some limitations. This study was completed with a small sample of eight participants from the same institution resulting in limited generalizability. Further studies with larger and more diverse samples (e.g., in terms of age, age of the children, employment status, caregiving responsibilities, from different higher education institutions) can be included in future research. Finally, political efforts to widen mature students' participation in higher education should consider work-family-school conflict as an essential issue to be addressed for a successful educational path, especially for women (Raaper \& Brown, 2020). Even though previous literature has already identified some needs of this population, the COVID-19 pandemic was an excellent opportunity for additional research on the effects of role boundary management of working student mothers, highlighting some barriers from the work, family, and school spheres that can hinder their educational journey and academic performance. Exploring strategies to overcome these barriers, both at the professional and educational level, is a pivotal issue to promote mature students' participation in higher education.

\section{REFERENCES}

Andrade, C., \& Matias, M. (2017). Adding school to work-family balance: The role of support for Portuguese working mothers attending a master's degree. Journal of Adult and Continuing Education, 23(2), 120. https://doi.org/10.1177/1477971417721717

Andrade, C., van Rhijn, T., \& Matias, M. (2017). School-to-Family and Family-to-School Enrichment in Women pursuing Post-Secondary Education. Revista Psychologica, 60(2), 101-116. https://doi.org/10.14195/1647-8606_60-2_6

Ashforth, B. E., Kreiner, G. E., \& Fugate, M. (2000). All in a day's work: Boundaries and micro role transitions. Academy of Management Review, 25, 472-491. https://doi.org/10.5465/amr.2000.3363315

Basch, C. E. (1987). Focus group interview: An underutilized research technique for improving theory and practice in health education. Health Education Quarterly, 14(4), 411-448. https://doi.org/10.1177/109019818701400404

Braun, V., \& Clarke, V. (2006). Using thematic analysis in psychology. Qualitative Research Psychology, 3, 77-101. http://dx.doi.org/10.1191/1478088706qp063oa

Braun, V., \& Clarke, V. (2013). Successful Qualitative Research: A Practical Guide for Beginners. Sage.

Carnevale, J. B., \& Hatak, I. (2020). Employee adjustment and well-being in the era of COVID-19: Implications for human resource management. Journal of Business Research, 116, 183-187. https://doi.org/10.1016/j.jbusres.2020.05.037

Chawla, N., MacGowan, R. L., Gabriel, A. S., \& Podsakoff, N. P. (2020). Unplugging or staying connected? Examining the nature, antecedents, and consequences of profiles of daily recovery experiences. Journal of Applied Psychology, 105(1), 19 -39. https://doi.org/10.1037/apl0000423

Choy, S. (2002). Nontraditional undergraduates (Report no NCES 2002-012). National Center for Education Statistics. https://eric.ed.gov/?id=ED546117

Cinamon, R. (2016). Integrating work and study among young adults: Testing an empirical model. Journal of Career Assessment, 24(3), 527-542. https://doi.org/10.1177/1069072715599404

Daly, K. J. (2007). Qualitative methods for family studies and human development. Sage Publications, Inc.

Home, A. M. (1997). Learning the hard way: Role strain, stress, role demands, and support in multiple-role women students. Journal of Social Work Education, 33(2), 335-347. https://doi.org/10.1080/10437797.1997.10778874

Lowe, J., \& Gayle. V. (2007) Exploring the work/life/study balance: the experience of higher education students in a Scottish further education college. Journal of Further and Higher Education, 31 (3), 225238. https://doi.org/10.1080/03098770701424942

Kreiner, G. E., Hollensbe, E. C., \& Sheep, M. L. (2009). Balancing borders and bridges: Negotiating the workhome interface via boundary work tactics. Academy of Management Journal, 52, 704-730. https://doi.org/10.5465/AMJ.2009.43669916

Nippert-Eng, C. E. (1996). Home and work. The University of Chicago Press.

Oliveira, M., \& Temudo, E. (2008). Mulheres Estudantes Trabalhadoras na Universidade do Porto - Uma licenciatura "fora de tempo" ou "sem tempo"? Ex-aequo, 18, 147-173. 
Park, Y., \& Sprung, J. M. (2013). Work-school conflict and health outcomes: Beneficial resources for working college students. Journal of Occupational Health Psychology, 18(4), 384-94. https://doi.org/10.1037/a0033614

Raaper R., \& Brown C. (2020) The Covid-19 pandemic and the dissolution of the university campus: implications for student support practice. Journal of Professional Capital and Community, 5(3/4), 343-349. https://doi.org/10.1108/JPCC-06-2020-0032

Van Rhijn, T. (2014). Barriers, Enablers, and Strategies for Success Identified by Undergraduate Student Parents. Canadian Journal for New Scholars in Education, 5(1), 1-10.

Sweet, S., \& Moen, P. (2007). Integrating educational careers in work and family: Women's return to school and family life quality. Community, Work \& Family, 10(2), 231-250. https://doi.org/10.1080/13668800701270166

UNESCO. (2020, September). COVID-19 Educational disruption and response. https://en.unesco.org/covid19/educationresponse

Wyland, R. L., Lester, S. W., Mone, M. A., \& Winkel, D. E. (2013). Work and school at the same time? A conflict perspective of the work-school interface. Journal of Leadership \& Organizational Studies, 20(3), 346357. https://doi.org/10.1177/1548051813484360

$\begin{array}{ll}\text { Historial do artigo } & \\ \text { Recebido } & 08 / 2020 \\ \text { Aceite } & 12 / 2020 \\ \text { Publicado online } & 03 / 2021 \\ \text { Publicado } & 06 / 2021\end{array}$

